University of New Hampshire

University of New Hampshire Scholars' Repository

$1-1-2004$

\title{
Above and below the water: Social/ecological transformation in northwest Newfoundland
}

\author{
Lawrence C. Hamilton \\ University of New Hampshire, Durham, lawrence.hamilton@unh.edu \\ Richard L. Haedrich \\ Memorial University of Newfoundland \\ Cynthia M. Duncan \\ The Ford Foundation, Mil.Duncan@unh.edu
}

Follow this and additional works at: https://scholars.unh.edu/soc_facpub

Part of the Sociology Commons

\section{Comments}

This is an Author's Manuscript. The final publication is available at Springer via https://dx.doi.org/10.1007/

s11111-004-4484-z

\section{Recommended Citation}

Hamilton, L.C., R.L. Haedrich \& C.M. Duncan. 2004. "Above and below the water: Social/ecological transformation in northwest Newfoundland." Population and Environment25(3):195-215.

This Article is brought to you for free and open access by the Sociology at University of New Hampshire Scholars' Repository. It has been accepted for inclusion in Sociology Scholarship by an authorized administrator of University of New Hampshire Scholars' Repository. For more information, please contact Scholarly.Communication@unh.edu. 
AUTHORS' DRAFT. Final version published at:

Hamilton, L.C., R.L. Haedrich \& C.M. Duncan. 2004. "Above and below the water:

Social/ecological transformation in northwest Newfoundland." Population and Environment 25(3):195-215.

\title{
ABOVE AND BELOW THE WATER SOCIAL/ECOLOGICAL TRANSFORMATION IN NORTHWEST NEWFOUNDLAND
}

Lawrence C. Hamilton

Sociology Department

University of New Hampshire

Richard L. Haedrich

Biology Department

Memorial University of Newfoundland

Cynthia M. Duncan

Community and Resource Development

The Ford Foundation

Acknowledgments: The North Atlantic Arc (NAArc) research project has been supported by grants from the Arctic System Science and Arctic Social Sciences programs of the U.S. National Science Foundation (OPP-9515380 and OPP-9912004), and from Canada's Natural Science and Engineering Research Council. Jeffrey Runge (University of New Hampshire) provided helpful suggestions on an earlier draft.

\begin{abstract}
Marine fisheries and fishing societies develop around the resources provided by a particular ecosystem. As they exploit these resources, fisheries transform the ecosystem, which pushes fishery and society to adapt in turn. This process is illustrated by fisheries, ecological and social data tracking dramatic changes on Newfoundland's Northern Peninsula and its adjacent marine ecosystem, the northern Gulf of St. Lawrence. There a longstanding fishery for cod and other groundfish collapsed in the 1990s, and was replaced by fisheries targeting invertebrates. The new invertebrate fisheries have different socioeconomic characteristics than the former groundfish fisheries. The shift in target species reflects deep ecological changes that were underway at least a decade before official recognition of the crisis. Our analysis of biological data reveals that the main ecological changes occurred during "the glory years" of the 1980s, when Newfoundland's domestic fisheries were at their peak. Overfishing and interactions with adverse climatic conditions drove the changes. As the ecosystem transformed, human population declined due to outmigration, and social indicators show signs of distress. Accounts by outport residents paint a generational picture of social change.
\end{abstract}

\section{KEYWORDS}

Newfoundland, fisheries, collapse, social, ecological 


\section{INTRODUCTION}

Fisheries are human systems, constructed to exploit living resources of a natural ecosystem. Characteristics of the ecosystem constrain its possible fisheries, and also help to shape the society that a fishery can support. The cod-dominated ecosystems of northwest Atlantic continental shelves, for example, influenced not only the pattern of early European settlement in North America, but also the trade, societal and political relations that those settlements later developed (Kurlansky, 1997).

Newfoundland's frequently icy coasts constrained the kind of settlements that could take root there, which differed from those along warmer coasts of the northeastern Atlantic. Even in the most fisheriesdependent societies, social forces play critical roles (e.g., Sider, 1986; Sinclair, 1988; Candow \& Corbin, 1997; Apostle et al., 1998). Underneath all the social influences, however, fisheries-dependent societies retain close links to their host ecosystems.

Ecosystems have dynamics of their own. The contemporary flora and fauna of the North Atlantic evolved within a highly variable ocean environment. This evolution has taken place over millions of years, while ice ages came and went, to produce the natural communities encountered by earlier generations of fisher folk. Large climatic variations on annual, decadal and longer time scales are commonplace in this region, and natural populations fluctuate in response (Jakobsson et al., 1994; Beamish, 1995). Predator-prey relationships and competition among species, embedded over multifaceted interactions between oceanic and climatic conditions, add to the ecological dynamics. Over the past five centuries, however, and even more over the past five decades, the ecology of the North Atlantic has been altered by humans - and in particular, by fisheries. As a fishery transforms its resource base, the fishery itself must change too, and along with it the fishing society.

Newfoundland's Great Northern Peninsula (Figure 1) is the most fisheriesdependent region of Canada's poorest and most fisheries-dependent province (Hamilton \& Butler, 2001). For centuries, rich cod resources supported scores of small outports along the rocky coasts. In the 1980s and $90 \mathrm{~s}$, as cod populations declined, many fisher folk faced the loss of traditional livelihoods, in an area with few alternative resources. Some were able to thrive in the emerging invertebrate fisheries, targeting shrimp and crab that grew more abundant as the predatory cod disappeared. Catching, processing and marketing the new "fish" required new investments, licenses and marketing arrangements, however, and supported fewer people than the former cod fishery. In this paper we bring together fisheries, ecological and social data to provide a glimpse of the feedbacks between natural and human systems.

\section{$<<$ Figure 1 about here $>>$}

\section{FISHERIES TRANSITION: FROM FISH TO INVERTEBRATES}

Abundant cod (Gadus morhua) in waters around Newfoundland were noticed by the explorer John Cabot in 1497. Systematic exploitation began in the 16th century; over the following centuries, these became one of the world's most productive fishing grounds. Cod were a primary motivation for European settlement on the island. Hundreds of small villages or outports grew along the rugged coastline in locations favorable for cod fishing. The harsh winters, rocky soils and remoteness of many outports discouraged economic development beyond fishing. After Newfoundland joined Canada in 1949, its population grew rapidly (from 320,000 in 1945 to over 570,000 by 1990); fishing intensified, and a tertiary economy bloomed. Newfoundland nevertheless remained Canada's poorest province and the one most dependent on federal aid. Away from the metropolitan center of St. John's, outport life generally centered around fishing (Matthews, 1976; Sinclair, 1985, 1988; Candow \& Corbin, 1997).

The 1992 collapse of the great cod population (called the Northern Cod) off northern and eastern Newfoundland marked an abrupt end to this five-century story. Warner (1997) provides an historical account of the advent of factory trawlers in the late 1950s, which subsequently led the way in depleting cod stocks. Finlayson (1994) takes a sociology-of-science perspective to show how Northern Cod stock 
assessments were (mis)constructed by managers over the years. Hannesson (1996) draws comparisons encompassing the failures of Norwegian, Faeroese and Icelandic cod fishery management at about the same time. Harris (1998) writes a detailed account of the political mistakes that led up to the Northern Cod crisis and continued in its aftermath. Hutchings and Myers (1995) provide historical analyses showing that contrary to popular beliefs, even the pre-industrial fishery was unsustainably consuming its resource base - albeit, more slowly than its modern counterpart. Biological analyses point to overfishing as the primary cause of the modern collapse (Hutchings \& Myers, 1994; Sinclair \& Murawski, 1997), with environmental conditions a contributing factor (Drinkwater, 2002). Despite a moratorium on Northern Cod fishing in 1992, and subsequent efforts at strict control, the stock failed to rebound. Even the limited fishing pressure of post-moratorium years was sufficient to prevent recovery; and if all fishing stopped, recovery would still take decades (Haedrich \& Hamilton, 2000; Hutchings, 2000). Finally, in April 2003, the federal government closed the Northern Cod fishery. Canada's Atlantic cod had become an endangered species.

Huge though it was, the Northern Cod collapse proved to be just one facet of a larger ecological transformation. Fisheries crises occurred throughout the northwest Atlantic during the early 1990s, from Greenland to New England (Murawski et al., 1997). Among those affected were cod of the northern Gulf of St. Lawrence (see Figure 1). Like the Northern Cod, the Gulf cod were a top predator, dominant in their ecosystem. Outports along the Northern Peninsula's west coast developed around northern Gulf cod fishing during the 19th and 20th centuries, with gradually rising levels of exploitation (Sinclair, 1985; Felt \& Sinclair, 1995). Figure 2 depicts cod and shrimp catches 1960-2002. The post-World War II foreign catch in the Gulf was proportionately lower than it was for the Northern Cod off northeast Newfoundland, but still amounted to roughly half of the total during the 1960s and early 1970s. Technological intensification of Northern Peninsula fishing after 1965 had partly ecological motivations. Offshore intensification occurred as the more accessible inshore stocks were depleted (Palmer \& Sinclair, 1997, p. 31). A "killer spike" of peak catches around 1968-70 reflected the new and unsustainably high capacity of both Canadian and foreign fleets. After Canada declared a 200-mile economic exclusion zone (EEZ) in 1976, foreign quotas were cut back and domestic fishing capacity expanded through subsidized investment. Canadian catches reached new highs in the late 1970s and early 1980s, then stayed above historical levels until the late 1980s. The fleet buildup had broad social effects, as it fostered within formerly egalitarian fishing communities a new elite of dragger skippers (Sinclair, 1985). Increasing Canadian efforts to manage the stocks also had the unintended effect of increasing unreported fishing (Palmer \& Sinclair, 1997, p. 47), so the 1980s peak in Figure 2 understates the actual catch.

$<<$ Figure 2 about here $>>$

During what Palmer and Sinclair's (1997) informants termed "the glory years" of 1982-1987, the Northern Peninsula's dragger fleet expanded, encouraged by state subsidies and the tremendous catches of larger vessels. After 1988, however, falling catches and quotas signaled a new era of decline. Inconsistent opinions and reports about the state of Gulf cod stocks floated through the Northern Cod moratorium in 1992. Some Northern Peninsula fishermen believed their Gulf stocks were healthier than the vanishing Northern Cod, whereas others thought that both stocks were similarly depleted — and resented the fact that federal assistance money was not equally available to fishermen in both areas. Ultimately, the Gulf cod proved to be vanishing too. The northern Gulf fishery was closed "temporarily" in 1993, and then came under a moratorium in 1994. Like the Northern Cod, northern Gulf cod continued to decline after the moratorium. Both fisheries were closed in 2003.

As cod catches declined in the early 1970s, and then again in the late 1980s, effort was redirected towards other species such as redfish (Sebastes) or Greenland halibut (Reinhardtius hippoglossoides). After shorter booms, these alternatives too faced depletion. Better prospects appeared in several invertebrate fisheries, notably northern shrimp (Pandalus borealis), American lobster (Homarus 
americanus) and snow crab (Chionoecetes opilio) - local manifestations of a worldwide shift towards lower trophic levels that Pauly et al. (1998) term "fishing down food webs." Lobstering, and to some extent fishing for scallop and shrimp, were already established traditions on the Northern Peninsula, but with new investments, ecological conditions and market demand they grew increasingly important. Shrimp and scallop presented the two main alternatives for draggers shut out by the 1994 cod moratorium. Figure 2 shows the rising shrimp catches (almost all by Canadians) in the northern Gulf over 1960-2002.

By the new millennium, the total value (in constant dollars) of the new invertebrate-based fisheries exceeded that of cod in its heyday. But the wealth not only came from different species (particularly shrimp and snow crab); it also was distributed differently on land. Landings value on the Northern Peninsula remained similar to the best cod years. Landings on the Avalon Peninsula increased, while those of southern Newfoundland - which lacked significant crustacean fisheries - declined (Hamilton \& Butler, 2001). Within each region, only fishermen with the proper licenses and gear, a fraction of the number in the former cod fishery, could bring in shrimp, crab or other invertebrates. Geography, marketing and investment decisions as well as licensing/quota rules all affected individuals' ability to adapt to a changing ecosystem. Skill differentials raised barriers and created opportunities.

\section{ECOLOGICAL TRANSFORMATION}

The fish-to-invertebrates transition of Northern Peninsula fisheries reflects underlying ecological change. Fishery catch statistics provide an imperfect picture, however. Technological advances and intensification of effort can allow catches to grow even while fish populations are falling. Moreover, some fraction of the catch - including most of the noncommercial species, as well as deliberate omissions about quota-regulated commercial species - is never reported. Scientific trawl surveys aim to provide alternative, unbiased estimates of resource abundance as a guide for management decisions. These have been conducted by the Department of Fisheries and Oceans (DFO). Our analyses in this section draw on DFO survey data, made available through the East Coast of North America Strategic Assessment Project (ECNASAP).

Figure 3 shows the numbers of cod caught per standardized trawl in northern Gulf of St. Lawrence (NAFO subareas 4RS) scientific surveys over 1983-94. Around 200-300 separate trawls were made each year in this region, roughly 3000 in all. Data points in Figure 3 denote the median and robust mean of the number of cod fish per trawl. The more commonly used arithmetic means are not shown here because they proved too sensitive to a few high outliers. In fact, we found that just three of these 3000 trawls would dominate our conclusions if looked only at arithmetic means (or sums). This statistical quirk has real consequences. For example, Palmer and Sinclair (1997, p. 77) note the dramatic shift in official perceptions about Gulf cod, from an "ecological disaster" in 1990, to being "on the road to recovery" in 1992, and then closed due to collapse in 1993-94. These shifts appear to track a singleyear (1991) spike in the number of northern Gulf cod caught in scientific surveys, which were the basis for biomass estimates. Our re-analysis uncovered the fact that the 1991 spike reflects a single anomalous trawl set, among the 278 such sets made that year. We find that robust estimation, employing the biweight algorithm described in Hamilton (1992), provides more plausible and efficient (narrowerconfidence-interval) measures of center for the purpose of identifying trends in the trawl survey data.

\section{$<<$ Figure 3 about here $>>$}

Judging from Figure 3, the abundance of northern Gulf cod declined precipitously during the glory years of 1983-87. After that it crept closer to zero, but the main ecological transformation took place during the fishery's high years, not its terminal phase. When some dragger skippers noticed that cod were becoming smaller and harder to find in the mid-80s, they adapted by illegally lining their nets 
with smaller-size mesh (Palmer \& Sinclair, 1997), effectively targeting the juvenile fish. Through this and other intensifications, catches in the final years remained deceptively high despite crashing stocks.

Curves similar to those in Figure 3 lead to the same conclusion if we employ the robust mean weight of cod per trawl (a biomass estimator), or the robust mean weight per fish (an individual-size estimator), as our measures of the health of cod stocks. Moreover, this collapse was not confined only to cod, or even to other commercial fish. Figure 4 graphs the robust mean weight per fish of nine "indicator species" which we selected on biological criteria. These nine types of fish include some with little commercial value, that could have been affected as bycatch and through the habitat disruption of trawling. They represent a wide range of ecological and temperature-depth niches. [1] (We do not, unfortunately, have comparable data on invertebrates, which were not adequately sampled for most of these years.) The lowest curve in Figure 4 depicts capelin, a small but important species - they are food for larger fish. Capelin themselves feed on zooplankton, so declining capelin signal trouble at the heart of the food web.

\section{$<<$ Figure 4 about here $>>$}

Declines in mean weight per fish combine two trends: reductions in size-at-age, and increasing scarcity of large older fish. Reductions in size-at-age could result from either fishing or environmental pressure; in this case it was probably both. The scarcity of older fish is primarily a fisheries effect. Large groundfish play a key role in ecosystems as top predators. Their removal is a worldwide phenomenon; Myers and Worm (2003) estimate that large predatory fish biomass is only about $10 \%$ of pre-industrial levels. Within species, smaller individuals may not yet be mature enough to have reproduced at all; indeed the mean sizes for several indicator species dropped below reproductive levels during this period. If catches consist largely of immature fish (a situation termed "recruitment overfishing") this bodes ill for a fishery's future. Smaller fish tend to be less valuable as well. When the average size of fish is falling, biomass-based fishing quotas lead to removing more individual fish from the sea. Moreover, any particular quota weight will be worth more if fishermen high-grade their catch, illegally dumping smaller fish at sea (Drinkwater, 2002). Thus, falling size interacts with economic considerations in ways that increase fishery impacts.

Figure 4 visualizes an ecosystem cascading downhill. As with Figure 3, most of the change occurred during the glory years, well before a crisis became official in 1993. Overfishing was likely the main driver. The physical environment was worsening too, however. Unusually cold, icy conditions occurred off north and east Newfoundland during the 1980s and 1990s, resulting from strong northerly winds associated with a prolonged positive state of the North Atlantic Oscillation (NAO) (Drinkwater, 2002). The same winds, and similarly cold winter conditions, prevailed in the Gulf of St. Lawrence. The lower curve in Figure 5 shows minimum temperatures in the Gulf's cold intermediate layer (CIL) below 100 meters. The CIL is formed annually by winter air cooling and the inflow of water from the Labrador Sea (Gilbert \& Pettigrew, 1997), both driven by northerly winds. The cold period of 1984-98 is the longest and most intense in this record. This is confirmed by other indicators, including the maximum extent of winter sea ice (upper curve in Figure 5). Ice area surpassed average levels from 1985 to 1996.

\section{$<<$ Figure 5 about here $>>$}

Colder conditions need not be fatal to north-adapted species. Using data from the Labrador Sea, Fischer and Haedrich (1999) demonstrated that even the coldest years there, the distribution of dangerously cold water was patchy and left much suitable habitat available for groundfish. Historically, Newfoundland's groundfish have survived other cold periods without collapse. By the 1980s, however, decades of fishing had removed many of the large older fish. Their removal left fish populations less reproductively robust (because older females produce more eggs and more viable offspring) at the same time the fishery became increasingly dependent on constant recruitment of young fish. Colder conditions slowed growth rates and reduced recruitment directly, which in turn exacerbated the impacts of fisheries 
removals and accelerated the vicious circle of dumping smaller-size fish. Drinkwater (2002) characterizes as "overwhelming" the evidence that overfishing was the main cause of the collapse of the

Northern Cod. He goes on to note, however, numerous ways in which the cold environment substantially contributed to this collapse. His arguments apply equally well to the northern Gulf cod, which exhibited declines in growth rates and size-at-age in the mid-1980s, and in body condition by 1989 (Lambert \& Dutil, 2000).

As the ecosystem was transformed, so too was the society it supported. The next two sections look at demographic and social changes on land.

\section{DEMOGRAPHIC TRENDS}

New economic realities and declines in traditional resources, combined with the pull of urban centers and non-fishing occupations, have produced a characteristic pattern of demographic change in fisheries-dependent regions across the North Atlantic Arc (Hamilton \& Otterstad, 1998; Hamilton \& Haedrich, 1999; Hamilton \& Butler, 2001; Hamilton, Colocousis, \& Johansen, 2003). Population declines reflect both outmigration by young adults, and reductions in historically high birthrates. Fishing-village residents are catching up but still tend to have less education, which is crucial for adaptation under shifting economic conditions. While some people do adapt and thrive, others depend increasingly on government.

Figure 6 shows changes in population over 1966-2002. The upper curve depicts Newfoundland as a whole, growing steeply over 1960-77, then more gradually until the Northern Cod moratorium in 1992. Much of this growth took place in southeast Newfoundland's Avalon Peninsula, which contains almost half the population and the capital city, St. John's (see Figure 1). After the moratorium, even the Avalon began to decline, and Newfoundland became the only Canadian province losing population.

$<<$ Figure 6 about here $>>$

A different story unfolded on the rural Northern Peninsula (lower curve in Figure 6). There, a period of growth accompanied the cod fishery expansion after Canada established its 200-mile EEZ in 1976. Population peaked in 1986, during the glory years, and thereafter began a slow decline — which steepened markedly as Gulf cod came under a moratorium in 1994.

Table 1 shows demographic profiles before, during and after the cod crises. Newfoundland has long been more fisheries-dependent than most of Canada, and the Northern Peninsula is the province's most fisheries-dependent region. Consequently, the crisis hit hard there. The percentage of the Northern Peninsula labor force in fishing fell from $20.5 \%$ to $14.4 \%$ in just five years, 1991-96. Reversing previous growth trends, population dropped by $3.6 \%$ over 1986-91, then plunged a further $8.7 \%$ over 1991-96. Reflecting its high birth rate, the Northern Peninsula's under-15 population was proportionately greater than Canada's in 1986 (30.4\% v. 25.9\%). A decade later, however, it had fallen slightly below national levels (20.2\% v. 20.5\%). Meanwhile the proportion 65 and over grew twice as fast on the Northern Peninsula (from $7.2 \%$ to $10.2 \%$ ) as it did in Canada as a whole (10.7\% to $12.2 \%$ ). Mean family size remained unchanged (3.1) for Canada during this period, while on the Northern Peninsula it dropped from a high level (3.7 in 1986) to one near the Canadian average (3.2 in 1996). Starting out far behind the rest of Canada, the Northern Peninsula saw progress in education and income. But in 1996 the Northern Peninsula still had more than twice Canada's proportion not completing 9th grade, and less than half the proportion with college degrees. The gap in median household income, $\$ 5,200$ in 1986, had widened to $\$ 9,300$ by 1996 .

Perhaps the most telling statistic in Table 1 is the proportion of income from government transfer payments. Even in 1986, at the height of the glory years, this amounted to $32.2 \%$ on the Northern Peninsula, and $21.2 \%$ in Newfoundland - compared with $11.1 \%$ in Canada. As the "employer of last resort," the cod fishery had long contained many more participants than it could support at full-time 
wages. Federal subsidies, particularly through Canada's unemployment system, helped keep outport families above water. Unfortunately the subsidies also muffled economic signals that fish resources, and hence the outports themselves, could not sustain so many people. Transfer support increased slightly by 1991, but jumped up after the codfish collapse. The redistribution of wealth accompanying fisheries transformations had been offset by subsidies, which in 1996 comprised nearly $40 \%$ of all income on the Northern Peninsula.

\section{AS SEEN FROM THE OUTPORT}

Statistical data broadly outline the cod fishery collapse, and its replacement by invertebrate fisheries. A compact historical account of social changes that accompanied fisheries changes on Newfoundland's Northern Peninsula appears in Palmer and Sinclair (1997). In this section, we add perspectives from outport residents who experienced the codfish collapse and its aftermath. Over 1997-1999 one of us (Duncan) conducted life-history interviews with a snowball sample of 40 people in a Northern Peninsula fishing community. Those interviewed included at least one member from every family, and a full range of adult generations. Their narratives break naturally into four historical eras, summarized below.

Traditional era (pre-1965). During the 1940s, people depended upon diverse local resources. Fishermen using small open boats focused on cod, lobster, seals and herring. Sealing began in March, and lobster fishing in April. Cod were fished in the summer months, and in the fall some fishermen went after herring. In winter, men worked at forestry, often in crowded and unsanitary camps. Forestry gave them an opportunity to earn cash; fish were commonly exchanged for credit with the local merchant, where families secured food staples and supplies. Women and children tended gardens and livestock. There was little exchange of money; most families carried a debt in the spring that was paid off with fish over the season.

Cod were caught by cod traps or hook and line. A portion of the cod was kept for personal consumption, forming the main staple of the outport diet. The remainder was sold to one of two or three local buyers, who salted it in large cement vats for distribution. Fishermen's work began before sunrise and did not end before dark; as one said, "They never saw the grass growin'." Boys entered the fishery as young as 12 or 13, with most leaving school by 15 .

Technological change (1965 - mid 1970s). Modernization and new technology led to changes in fishing, work, education, family and community. Outports went through modernization with the advent of year-round road access and electricity. Population grew, propelled by the Smallwood Resettlement Project (which sought to close down many of the smaller, less viable outports), migration and natural growth. More men began completing 11th or 12th grade, and some went on to college or trade schools even if they intended to return to fishing. For the first time, young men had more than one option to choose from. People began working nearly year round at the same job. Unemployment benefits were developed in 1965, initially just for woodsmen but subsequently extended to fishermen and fish plant workers.

Fishing changed as new technology for catching cod and shrimp developed, and boats became larger. A handful of fishermen shifted to trawling or "dragger" gear. The federal government played a decisive role introducing new technology and providing financial resources to fishermen who were willing to take the risk of investing in new gear and larger boats. The early adopters were viewed with some skepticism by their peers. But technological change allowed new flexibility in shifting among boat sizes, gears and species.

Boom Era (mid 1970s - mid/late 1980s). A boom period followed Canada's assertion of a 200mile EEZ in 1976, and the buildup of domestic capacity. Fishermen in open boats and some long-liners continued to fish cod, lobster and seal inshore. Meanwhile draggers and other long-liners moved onto the 
open ocean, pursuing cod and shrimp nearly year round. At the height of the boom, dragger captains made \$350,000-600,000 a year from cod alone. Sharemen, many of them high school students on their fathers' boats, could earn $\$ 50,000$ a year. The federal government helped finance boat improvements, providing grants covering $30-40 \%$ of their cost.

The growth of dragging brought increasingly serious problems with bycatch, which killed large quantities of juvenile fish and nontargeted species. Inshore fishermen began to complain of declining fish abundance, and blaming the draggers.

"I mean, they used mesh $1 / 2$ inch big, right? Nothin', nothin' went through that, right?

We couldn't get no fish and they were still destroyin' it."

While inshore fishermen struggled, the draggers' offshore catches remained high. The outport had formerly seemed a place where everyone, apart from the merchants, was on an even keel. Now the increasing income of dragger owners and sharemen was changing that picture.

“Guys were makin' big bucks and the other guys were just survivin'. Just livin' from

day to day, where the other guys were drivin' fancy skidoos and two vehicles...."

By the late 1980s, some fishermen recognized signs of decline. Open boats and long-liners could rarely reach their quotas. To find the remaining cod, fishermen traveled farther north, deployed more gear and intensified their efforts. A few began shifting to alternative species such as crab. Cheating fisheries regulation - by selling unreported catches at night, lining nets with small mesh and dumping bycatch at sea - was said to be commonplace.

"Seen it all. Land in the middle of night. Stay out in boat until dark and come in twelve or one o'clock. Whenever, when the community's asleep. [No] log book and be gone out in boat even before day is broke."

Large illegal catches on top of too-high legal quotas drew down the resource. Some say they saw trouble coming, but felt powerless to halt it.

"But then, you know, that change when, when the fish started decline and we, and we all could see what was happenin'. I mean they were fishin', right and then their fish would get smaller and smaller and smaller and smaller...."

Bust and change (late 1980s-present). The 1994 moratorium had its most immediate impact on the town's 400 fish plant workers, who were put out of work overnight. Draggers' incomes fell sharply, but they could still make good money from shrimp. Open boaters who had relied solely on cod were hit hard; without a shrimp license they had no other source of income. To adapt following the moratorium, fishermen changed their equipment and target species. Decisions to invest in new equipment or boat improvements hinge on government regulations about which species can be fished, how large are the quotas, and who gets the permits. Participation in what remained of the cod fishery became a matter of luck, offering little stability: the government ran a lottery each year that allocated one-year cod licenses to $1 / 4$ th of the local draggers. In 2003 the cod fishery closed down.

The nature of work has changed. Most fishermen make a more modest living, catching smaller quotas from a greater mix of species. Many agree that the future of their community depends on a diverse fishery, following conservative quota management. The Nordmore Grate, a technological innovation that reduces bycatch in the shrimp fishery, has overcome initial resistance and become a symbol of new awareness that resources must be protected. Mothers and wives of fishermen remark on how work has changed for the men: it is hard for young men to start up or get by in fishing; but on the other hand they have more leisure time than their fathers did. Despite some optimism, there also is widespread concern that even present levels of fishing will prove unsustainable. Young people stay in school longer, and often leave home to pursue educations and careers elsewhere.

New levels of understanding regarding fishing technologies, government regulation and ecology can be seen in comments from the current participants. For example, some see a connection between the 
scarcity of cod and the abundance of shrimp, or between both and oceanographic conditions. Others questioned whether the government's sentinel-fishery policy, which allowed limited fishing ostensibly to monitor cod abundance, would in fact prevent cod recovery. While some complain that they can't get licenses for certain species, others worry that there are too many licenses already. From whatever perspective, the complex and changeable regulatory environment holds a central place in current fishermen's views.

\section{CONCLUSION}

The expansion of northwest Newfoundland's cod fishery, once viewed as a socioeconomic transformation, now appears to have been forced partly by ecological change - depletion of the most accessible groundfish stocks. By increasing the seasonal and geographic scope of the fishery, as well as its efficiency, fishermen could bring home increasing catches despite declining resource abundance. But this temporary success, reaching its height during the "the glory years" of the mid-1980s, hastened the transformation of the marine ecosystem around which outport society was built. Today a changed fishing society survives around the invertebrate-dominated ecosystem. Under pressure from new fisheries, that ecosystem continues to change, and further depletion remains a concern (for example, see Harris, 1998).

New regulatory and ecological conditions have made fishing livelihoods less predictable for many participants. There exists today less scope for the labor-intensive, low-technology sector that made the cod fishery the foundation for Newfoundland's traditional outport society. Many outport populations are declining, and increasingly dependent upon government assistance (Hamilton \& Butler, 2001). As women's roles change, birth rates are falling towards the national norm, and cannot compensate for outmigration. Young people stay longer in school, which makes them better prepared than earlier generations to move away and pursue opportunities elsewhere. Among those who remain in outport fishing, we find a new generation of fishermen now in middle age, better educated, more businesslike and generally more savvy - about technology, government and resource limitations - than their fathers.

The social changes associated with fisheries transformation resemble an acceleration of broad trends towards modernization. Details from participants' accounts, or in the timing of demographic changes, make clear their ecological dimensions. Modernization effects are hastened as an earlier traditional fishery, following its fish, fades away. Some people adapt to a more regulated and technical new fishery. Others leave, and find non-fishing livelihoods. A third element neither adapts nor leaves, but remains in place and on government assistance. The demographic and social shifts of Newfoundland's Northern Peninsula, which follow a pattern seen in other fisheries-dependent regions, reflect these three elements of change. 


\section{REFERENCES}

Beamish, R. J. (Ed.) (1995). Climate Change and Northern Fish Populations. Ottawa: National Research Council of Canada.

Candow, J. E., \& Corbin, C. (1997). How Deep is the Ocean? Historical Essays on Canada's Atlantic Fishery. Sydney, NS: University College of Cape Breton Press.

DFO (Department of Fisheries and Oceans) Canada (2000). Northern (2J 3KL) Cod. DFO Science Stock Status Report A2-01.

DFO (2003). http://www.meds-sdmm.dfo-mpo.gc.ca/alphapro/zmp/climate/climate_e.shtml

Drinkwater, K. F. (2002). A review of the role of climate variability in the decline of northern cod. American Fisheries Society Symposium, 32, 113-130.

Felt, L. F., \& Sinclair, P. R. (Eds.) (1995). Living on the Edge: The Great Northern Peninsula of Newfoundland. St. John's, Newfoundland: Institute for Social and Economic Research.

Finlayson, A. C. (1994). Fishing for Truth: A Sociological Analysis of Northern Cod Stock Assessments from 1977-1990. St. John's, Newfoundland: Institute for Social and Economic Research.

Fischer, J., \& Haedrich, R. L. (1999). Changes in the temperature/depth niche occupied by demersal fishes in the Northwest Atlantic between 1978 and 1993. Archives of Fisheries and Marine Research, $47(1), 1-15$.

Fischer, J. \& Haedrich, R. L. (2000). The realized annual niche space of common fish species off Newfoundland. NAFO Scientific Council Studies, 33, 11-28.

Gilbert, D., \& Pettigrew, B. (1997). Interannual variability (1948-1994) of the CIL core temperature in the Gulf of St. Lawrence. Canadian Journal of Fisheries and Aquatic Science, 54 (Suppl. 1), 57-67.

Haedrich, R. L., \& Hamilton, L. C. (2000). The fall and future of Newfoundland's cod fishery. Society and Natural Resources, 13, 359-372.

Hamilton, L. C. (1992). Regression with Graphics. Pacific Grove, CA: Brooks/Cole.

Hamilton, L. C., \& Butler, M. J. (2001). Outport adaptations: Social indicators through Newfoundland's cod crisis. Human Ecology Review, 8(2), 1-11.

Hamilton, L. C., Colocousis, C., \& Johansen, S. T. F. (2004). Migration from resource depletion: The case of the Faroe Islands. Society and Natural Resources 17(5).

Hamilton, L. C., \& Haedrich, R. L. (1999). Ecological and population changes in fishing communities of the North Atlantic Arc. Polar Research, 18(2), 383-388. 
Hamilton, L. C., \& Otterstad, O. (1998). Demographic change and fisheries dependence in the northern Atlantic. Human Ecology Review, 5(1), 24-30.

Hannesson, R. (1996). Fisheries Mismanagement: The Case of the North Atlantic Cod. Oxford: Fishing News Books.

Harris, M. (1998). Lament for an Ocean: The Collapse of the Atlantic Cod Fishery. Toronto: McClelland and Stewart.

Hutchings, J. A., \& Myers, R. A. (1994). What can be learned from the collapse of a renewable resource? Atlantic cod, Gadus morhua, of Newfoundland and Labrador. Canadian Journal of Fisheries Aquatic Science, 51, 2126-2146.

Hutchings, J. A., \& Myers, R. A. (1995). The biological collapse of Atlantic cod off Newfoundland and Labrador: An exploration of historical changes in exploitation, harvesting technology, and management. In R. Arnason \& L. F. Felt (Eds.), The North Atlantic Fishery: Strengths, Weaknesses, and Challenges (pp. 37-93). Charlottetown, PEI: Institute of Island Studies.

Huchings, J. A. (2000). Collapse and recovery of marine fishes. Nature, 406, 882-885.

Jakobsson, J., Astthorsson, O. S., Beverton, R. J. H., Björnsson, R., Daan, N., Frank, K. T., Meincke, J., Rothschild, B., Sundby, S., \& Tilseth, S. (Eds.) (1994). Cod and Climate Change. Proceedings of a Symposium Held in Reykjavik. Copenhagen: International Council for the Exploration of the Sea (ICES).

Kurlansky, M. (1997). Cod. A Biography of the Fish That Changed the World. Toronto: Alfred A. Knopf.

Lambert, Y. \& Dutil, J.-D. (2000). Energetic consequences of reproduction in Atlantic cod (Gadus morhua) in relation to spawning level of somatic energy reserves. Canadian Journal of Fisheries and Aquatic Science, 57, 815-825.

Matthews, R. (1976). There's No Better Place Than Here. Toronto: Peter Martin Associates.

Murawski, S. A., Maguire, J-J., Mayo, R. K, \& Serchuk, F. M. (1997). Groundfish stocks and the fishing industry. In J. Boreman, B. S. Nakashima, J. A. Wilson, \& R. L. Kendall (Eds.), Northwest Atlantic Groundfish: Perspectives on a Fishery in Collapse (pp. 27-70). Bethesda, MD: American Fisheries Society.

Myers, R. A., \& Worm, B. (2003). Rapid worldwide depletion of predatory fish communities. Nature, 423, 280-283.

NAFO (Northwest Atlantic Fisheries Organization) (2003).

http://www.nafo.ca/activities/FRAMES/AcFrFish.html

Newfoundland and Labrador Statistics Agency (2003). http://www.nfstats.gov.nf.ca/ 
Palmer, C. T., \& Sinclair, P. R. (1997). When the Fish Are Gone: Ecological Disaster and Fishers in Northwest Newfoundland. Halifax, NS: Fernwood Publishing.

Pauly, D., Christensen, V., Dalsgaard, J., Froese, R., \& Torres, F. Jr. (1998). Fishing down marine food webs. Science, 279:860-863.

Rothschild, B. J., Sharov, A. F., \& Lambert, M. (1997). Single-species and multispecies management. In Northwest Atlantic Groundfish. In J. Boreman, B. S. Nakashima, J. A. Wilson, \& R. L. Kendall (Eds.), Northwest Atlantic Groundfish: Perspectives on a Fishery in Collapse (pp. 141-152). Bethesda, MD: American Fisheries Society.

Sinclair, P. R. (1985). From Traps to Draggers: Domestic Commodity Production in Northwest Newfoundland. St. John's, Newfoundland: Institute for Social and Economic Research.

Sinclair, P. R. (Ed.) (1988). A Question of Survival: The Fisheries and Newfoundland Society. St. John's, Newfoundland: Institute for Social and Economic Research.

Sinclair, A. F., \& Murawski, S. A. (1997). Why have groundfish stocks declined? In J. Boreman, B. S. Nakashima, J. A. Wilson, \& R. L. Kendall (Eds.), Northwest Atlantic Groundfish: Perspectives on a Fishery Collapse (pp. 71-93). Bethesda MD: American Fisheries Society.

Warner, W. W. (1997). The fish killers. In J. E. Candow \& C. Corbin (Eds.), How Deep is the Ocean? Historical Essays on Canada's Atlantic Fishery (pp. 223-242). Sydney, NS: University College of Cape Breton Press.

\section{NOTE}

[1] We selected nine "indicator species" of fish for which comparatively good data exist, and which have historically been ecologically (though not always commercially) important in Newfoundland waters. Following the framework developed by Fischer and Haedrich $(1999,2000)$, we also sought species representing a variety of different "niche breadths," or range of temperature-depth preferences. The indicator species shown in Figure 4 are:

Niche breadth: strict

Redfish (Sebastes)

Capelin (Mallotus villosus)

Yellowtail flounder (Limanda ferruginea)

Niche breadth: clear

Atlantic wolffish (Anarhichas lupus)

Witch flounder (Glyptocephalus cynoglossus)

Greenland halibut (Reinhardtius hippoglossoides)

Niche breadth: broad

Atlantic cod (Gadus morhua)

American plaice (Hippoglossoides platessoides)

Niche breadth: very broad

Thorny skate (Raja radiata)

Our indicator species include representatives from each of the assemblages of northwest Atlantic groundfish identified in Rothschild, Sharov, and Lambert (1997, p. 148). 
Table 1: Profiles of Canada, the province of Newfoundland, and Newfoundland's Northern Peninsula, from the 1986, 1991 and 1996 Censuses. Data source: Statistics Canada.

\begin{tabular}{|c|c|c|c|c|}
\hline & & 1986 & 1991 & 1996 \\
\hline \multirow[t]{3}{*}{ \% labor force fishing } & Canada & - & 0.3 & 0.3 \\
\hline & Newfoundland & - & 4.6 & 3.8 \\
\hline & Northern Pen. & - & 20.5 & 14.4 \\
\hline \multirow{3}{*}{$\begin{array}{l}\text { Total population } \\
\text { in thousands }\end{array}$} & Canada & 26,204 & 28,120 & 29,672 \\
\hline & Newfoundland & 578 & 579 & 560 \\
\hline & Northern Pen. & 26 & 25 & 23 \\
\hline \multirow{3}{*}{$\begin{array}{l}\% \text { population change } \\
\text { over last } 5 \text { years }\end{array}$} & Canada & +4.0 & +7.9 & +5.7 \\
\hline & Newfoundland & +0.1 & 0 & -2.9 \\
\hline & Northern Pen. & +0.8 & -3.6 & -8.7 \\
\hline \multirow{3}{*}{$\begin{array}{l}\% \text { population }<15 \\
\text { years old }\end{array}$} & Canada & 25.9 & 20.9 & 20.5 \\
\hline & Newfoundland & 29.5 & 22.5 & 19.9 \\
\hline & Northern Pen. & 30.4 & 23.4 & 20.2 \\
\hline \multirow{3}{*}{$\begin{array}{l}\% \text { population } \geq 65 \\
\text { years old }\end{array}$} & Canada & 10.7 & 11.6 & 12.2 \\
\hline & Newfoundland & 8.8 & 9.7 & 10.8 \\
\hline & Northern Pen. & 7.2 & 8.5 & 10.2 \\
\hline \multirow[t]{3}{*}{ Mean family size } & Canada & 3.1 & 3.1 & 3.1 \\
\hline & Newfoundland & 3.6 & 3.3 & 3.1 \\
\hline & Northern Pen. & 3.7 & 3.4 & 3.2 \\
\hline \multirow{3}{*}{$\begin{array}{l}\% \text { population } \geq 15 \\
\text { years, w/o grade } 9\end{array}$} & Canada & 17.3 & 13.9 & 12.1 \\
\hline & Newfoundland & 26.6 & 20.4 & 17.5 \\
\hline & Northern Pen. & 38.6 & 32.6 & 27.9 \\
\hline \multirow{3}{*}{$\begin{array}{l}\% \text { population } \geq 15 \\
\text { years, } w / \text { college }\end{array}$} & Canada & 9 & 11.2 & 13.3 \\
\hline & Newfoundland & 5 & 6.6 & 8.1 \\
\hline & Northern Pen. & 2 & 3.6 & 4.9 \\
\hline \multirow{3}{*}{$\begin{array}{l}\text { Median household } \\
\text { income, } 1000 \text { CAD }\end{array}$} & Canada & 29.5 & 39.0 & 40.2 \\
\hline & Newfoundland & 24.6 & 34.0 & 34.0 \\
\hline & Northern Pen. & 24.3 & 32.5 & 30.9 \\
\hline \multirow{3}{*}{$\begin{array}{l}\% \text { income from govt. } \\
\text { transfer payments }\end{array}$} & Canada & 11.1 & 11.4 & 14.0 \\
\hline & Newfoundland & 21.2 & 21.1 & 24.6 \\
\hline & Northern Pen. & 32.2 & 33.9 & 39.4 \\
\hline
\end{tabular}




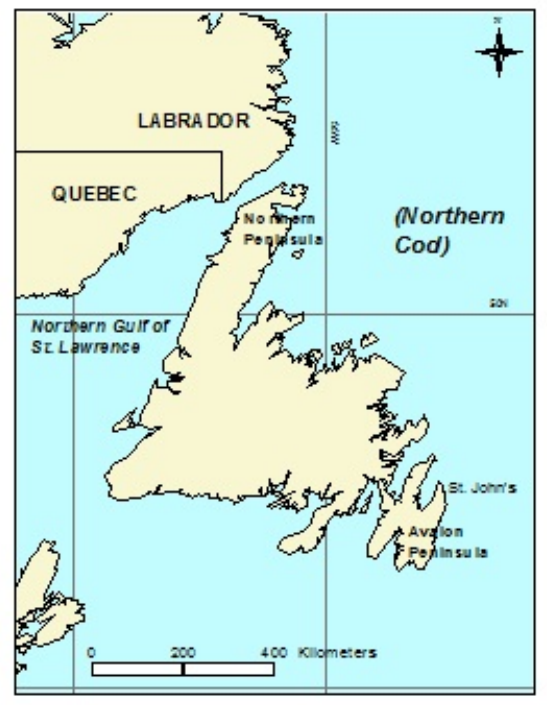

Figure 1: The island of Newfoundland, showing Northern Peninsula, northern Gulf of St. Lawrence, and the home of the Northern Cod.

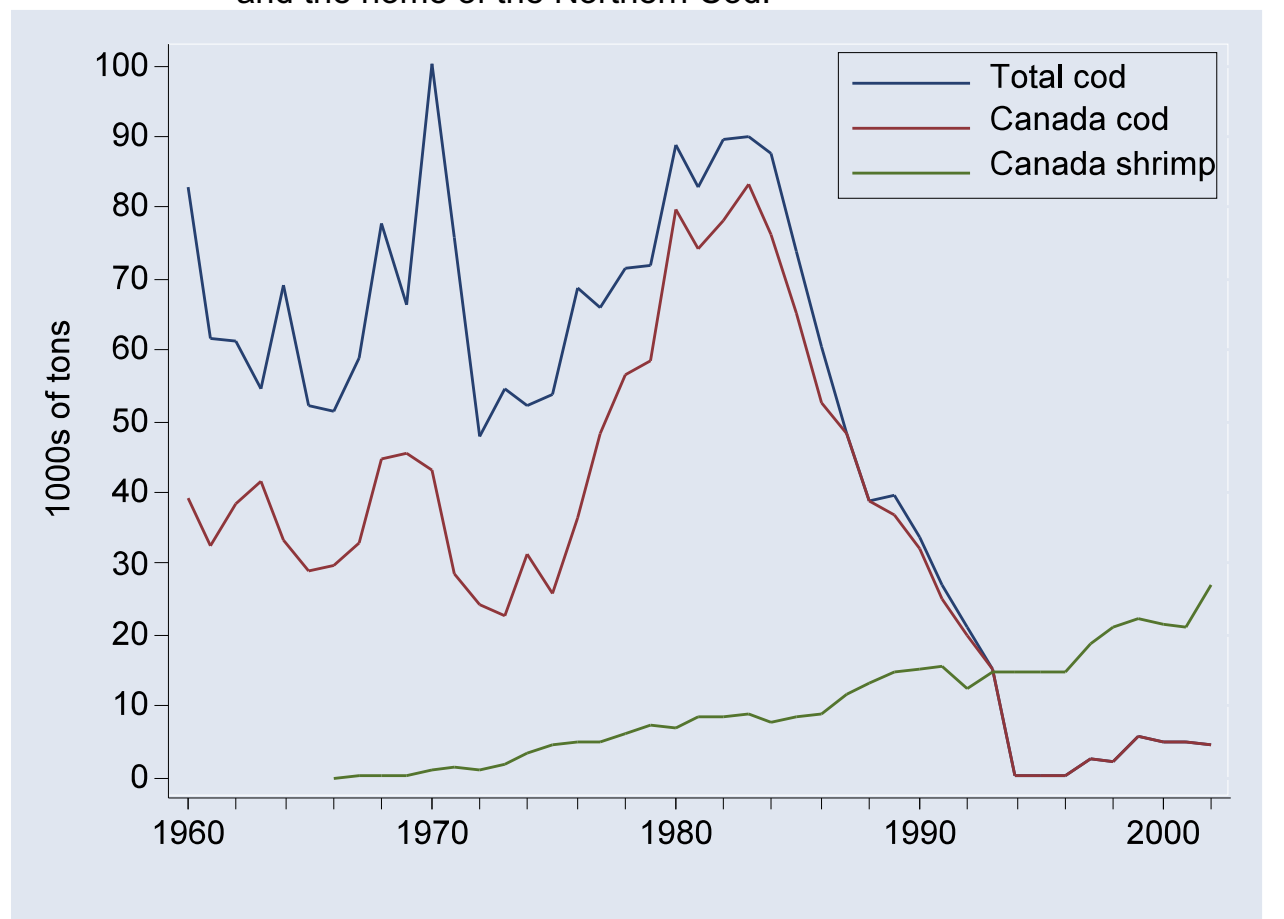

Figure 2: Cod and shrimp catches in the northern Gulf of St. Lawrence (NAFO subareas 4RS), 1960-2002. Data source: NAFO (2003). 


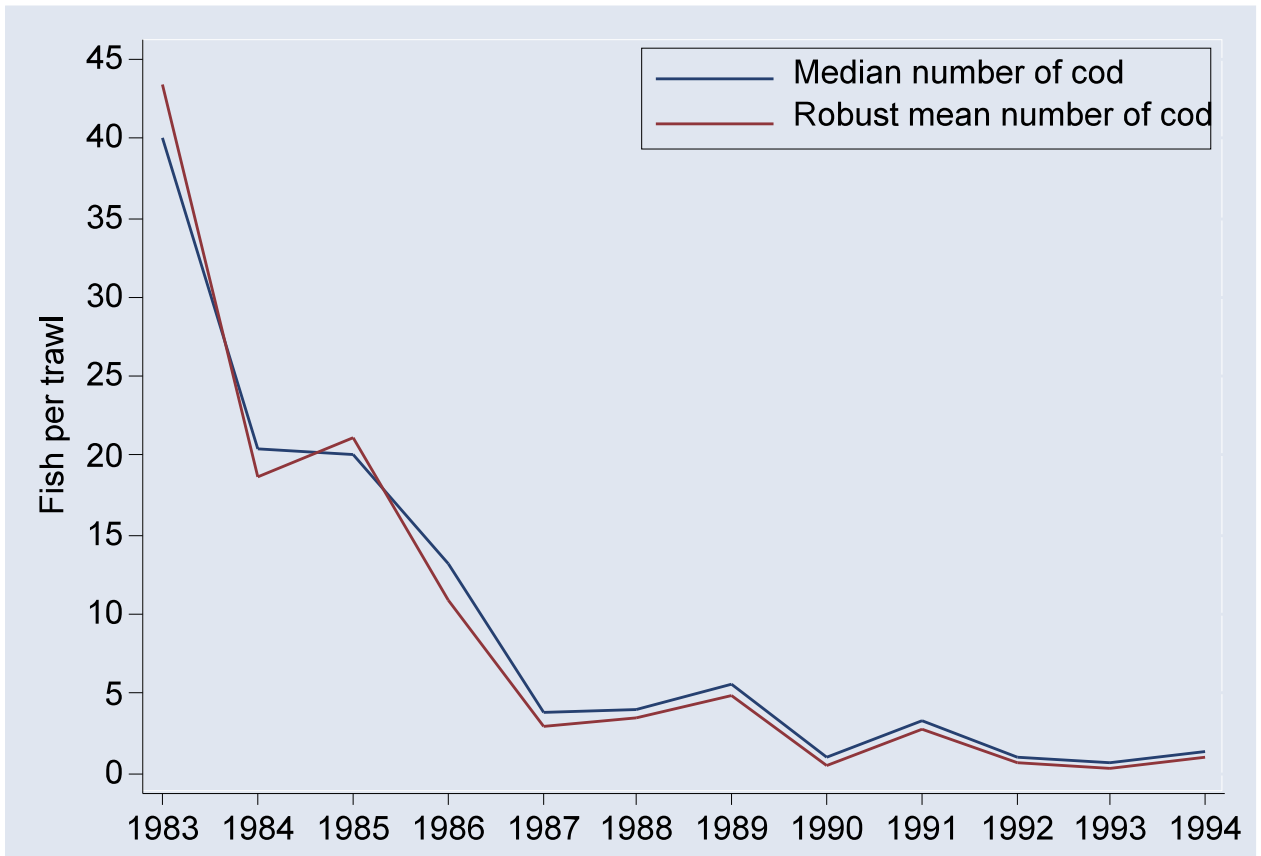

Figure 3: Median and robust mean numbers of cod caught per trawl by scientific surveys in the northern Gulf, 1983-94. Data source: DFO/ECNASAP.

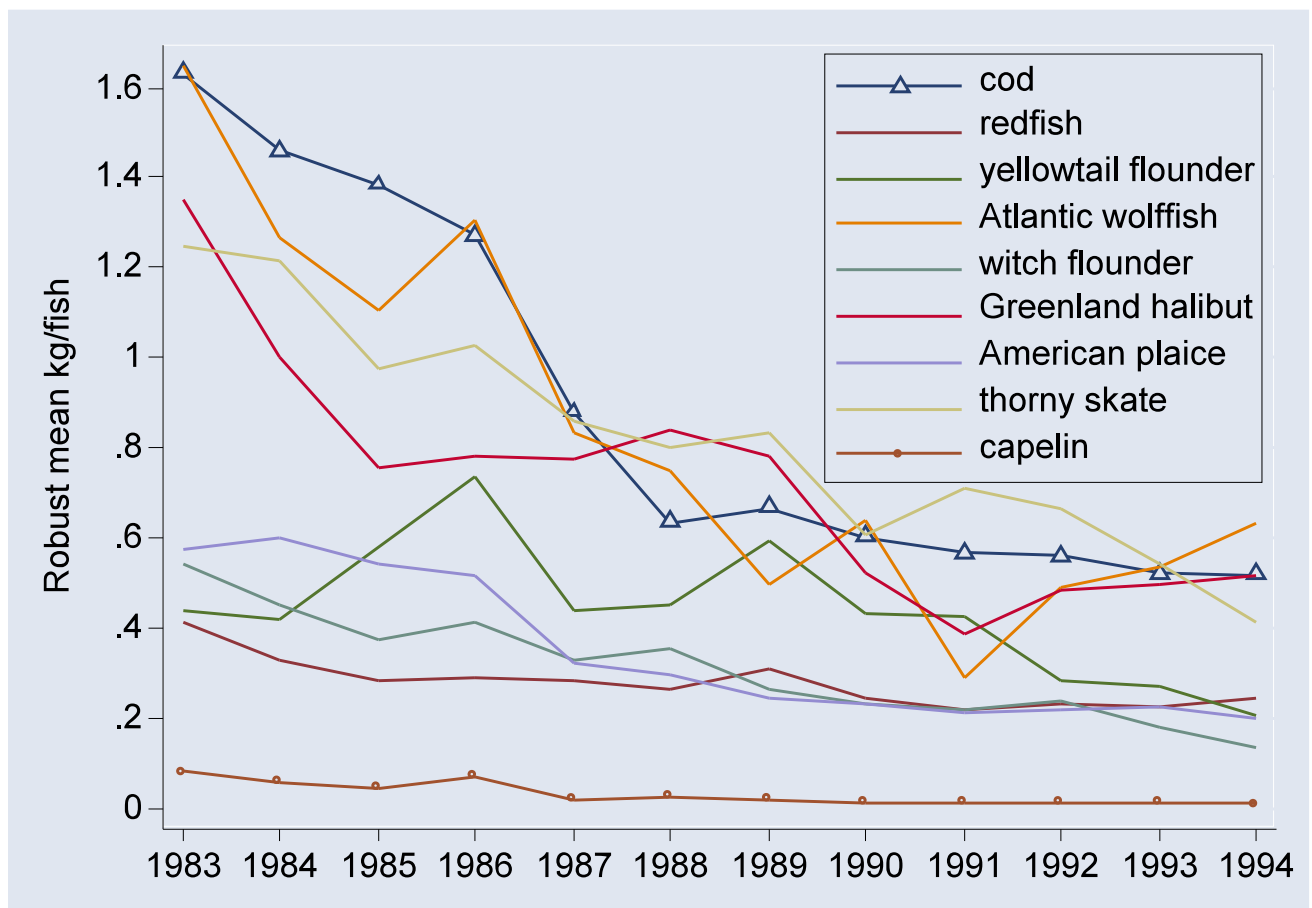

Figure 4: Robust mean weight per fish of nine indicator species, caught by scientific surveys in the northern Gulf 1983-94. Data source: DFO/ECNASAP. 


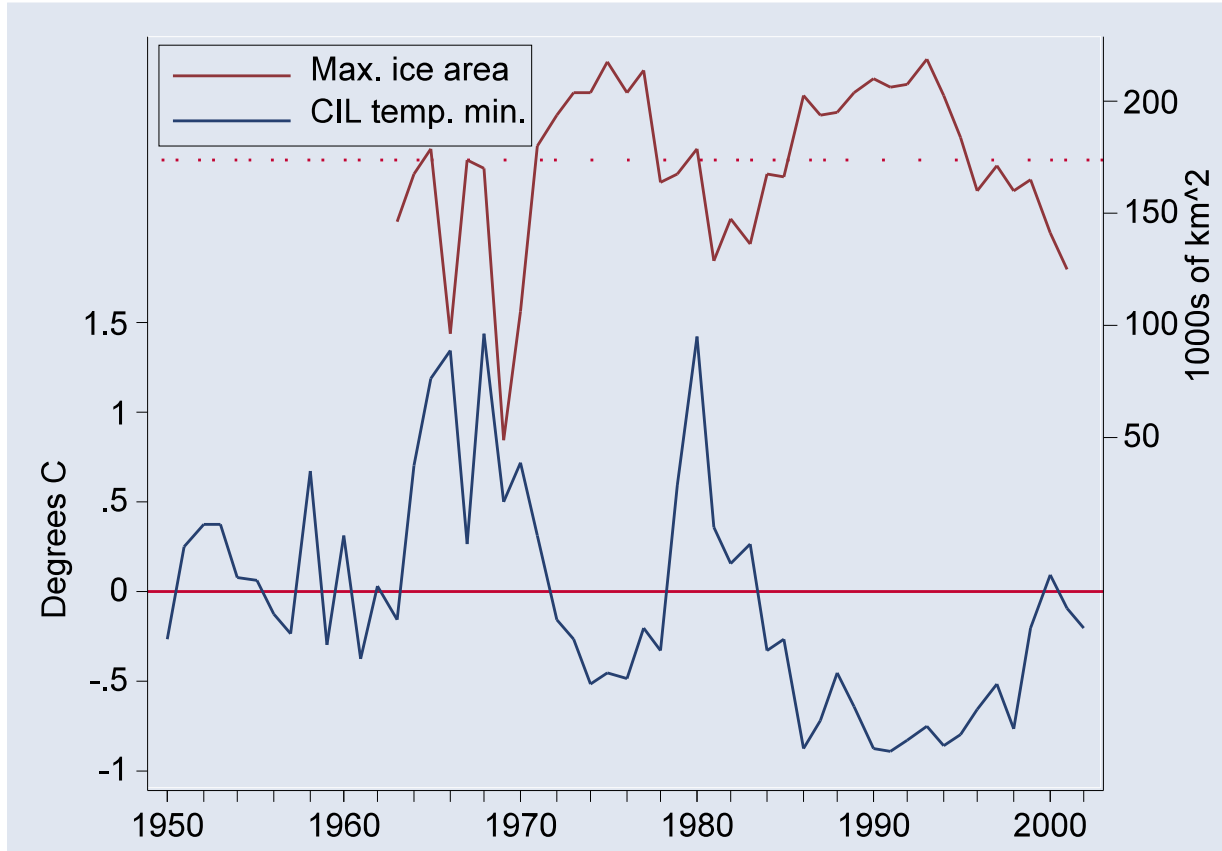

Figure 5: Minimum temperature of the Cold Intermediate Layer in the Gulf of St. Lawrence, 1950-2002 (lower curve). Upper curve shows the maximum area of winter ice cover, 1983-2001. Data source: DFO 2003; see Gilbert and Pettigrew (1997) for details.

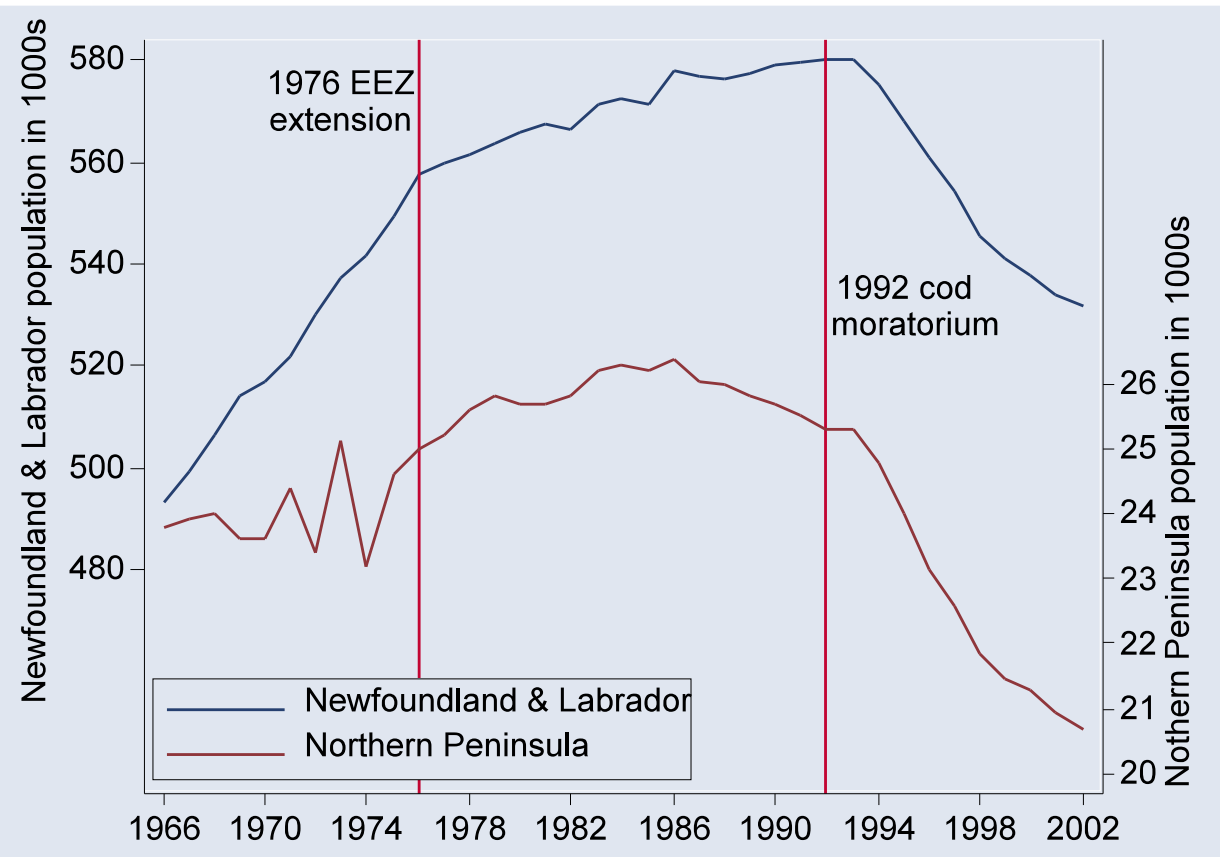

Figure 6: Population of Newfoundland and Labrador, and of the Northern Peninsula only, 1966-2002. Data source: Newfoundland and Labrador Statistics Agency (2003). 